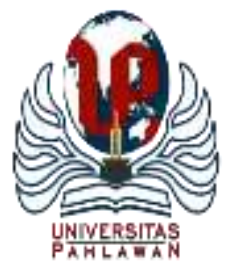

Edukatif : Jurnal Ilmu Pendidikan Volume 4 Nomor 1 Tahun 2022 Halm 934 - 943

EDUKATIF: JURNAL ILMU PENDIDIKAN

Research \& Learning in Education

https://edukatif.org/index.php/edukatif/index

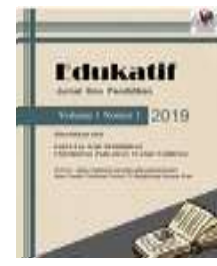

\title{
Persepsi Mahasiswa Terhadap Desain Implementasi Merdeka Belajar Kampus Merdeka: Survei pada Program Studi Ilmu Hukum Universitas Flores
}

\author{
Konstantinus Denny Pareira Meke ${ }^{1 凶}$, Richardo Barry Astro ${ }^{2}$, Christina Bagenda ${ }^{3}$, \\ Sumirahayu Sulaiman ${ }^{4}$, Paulinus Seda ${ }^{5}$, Ana Maria Gadi Djou ${ }^{6}$ \\ Universitas Flores, Ende, Indonesia ${ }^{1,2.3,4,5,6}$ \\ E-mail : dennyz.pareira@gmail.com ${ }^{1}$, richardobarryastro@gmail.com ${ }^{2}$, bagendatitin@ gmail.com $^{3}$, \\ ayusulaiman13@gmail.com ${ }^{4}$, paulinus_seda@uniflor.ac.id ${ }^{5}$, emmi_gadidjou12@uniflor.ac.id ${ }^{6}$
}

\begin{abstract}
Abstrak
Merdeka Belajar Kampus Merdeka (MBKM) adalah program pembelajaran pendidikan tinggi yang mandiri dan serbaguna yang dirancang untuk menciptakan komunitas pembelajaran kreatif yang tidak membatasi yang memenuhi kebutuhan mahasiswa Penelitian ini bertujuan untuk untuk melihat dampak dan persepsi penerapan Merdeka Belajar Kampus Merdeka (MBKM) kepada seluruh mahasiswa di perguruan tinggi swasta dengan tujuan untuk melihat sejauh mana pemahaman dan persepsi mahasiswa dan dampak dari penerapan program Merdeka Belajar Kampus Merdeka (MBKM) yang ada di Perguruan Tinggi. Penelitian ini merupakan penelitian deskriptif dengan pendekatan kuantitatif dengan metode survei. Data diperoleh dari populasi yakni 279 responden yang merupakan mahasiswa Program Studi Ilmu Hukum Fakultas Hukum Universitas Flores. Data dikumpulkan melalui kuesioner. Teknik analisis data dimulai dari pengumpulan data kemudian dianalisis menggunakan analisis deskriptif. Hasil dari penelitian survei ini menunjukan bahwa mahasiswa pada Program Studi Ilmu Hukum, Fakultas Hukum, Universitas Flores memberikan respon yang positif terhadap program Merdeka Belajar Kampus Merdeka (MBKM).
\end{abstract}

Kata Kunci: Survei, Merdeka Belajar Kampus Merdeka, Mahasiswa

\section{Abstract}

Independent Learning-Independent Campus (MBKM) is an independent and versatile higher education learning program designed to create an unrestricted creative learning community that meets the needs of students. All students in private universities to see the extent of student understanding and perception and the impact of implementing the Independent Learning-Independent Campus (MBKM) program in universities. This research is descriptive research with a quantitative approach with a survey method. Data were obtained from the population, namely, 279 respondents who were students of the Law Study Program, Faculty of Law, University of Flores. Data were collected through a questionnaire. The data analysis technique started from data collection and then analyzed using descriptive analysis. The results of this survey research show that students in the biology education study program, Faculty of Law the University of Flores gave a positive response to the Independent Learning-Independent Campus (MBKM) program.

Keywords: Survei Method, Independent Learning Independent Campus, College Students

Copyright (c) 2022 Konstantinus Denny Pareira Meke, Richardo Barry Astro, Christina Bagenda, Sumirahayu Sulaiman, Paulinus Seda, Ana Maria Gadi Djou

$\triangle$ Corresponding author:

Email : dennyz.pareira@gmail.com

DOI : https://doi.org/10.31004/edukatif.v4i1.2060

ISSN 2656-8063 (Media Cetak)

ISSN 2656-8071 (Media Online)

Edukatif : Jurnal Ilmu Pendidikan Vol 4 No 1 Tahun 2022 p-ISSN 2656-8063 e-ISSN 2656-8071 
935 Persepsi Mahasiswa Terhadap Desain Implementasi Merdeka Belajar Kampus Merdeka: Survei pada Program Studi Ilmu Hukum Universitas Flores - Konstantinus Denny Pareira Meke, Richardo Barry Astro, Christina Bagenda, Sumirahayu Sulaiman, Paulinus Seda, Ana Maria Gadi Djou

DOI: https://doi.org/10.31004/edukatif.v4i1.2060

\section{PENDAHULUAN}

Kementerian Pendidikan, Kebudayaan, Riset, dan Teknologi (Kemenristekdikti) tengah menggalakkan kebijakan Merdeka Belajar-Kampus Merdeka (MBKM). Kebijakan yang diperkenalkan oleh Menteri Pendidikan dan Kebudayaan Nadiem Anwar Makarim pada Januari-Februari 2020 ini menyasar pendidikan tinggi (Margiato, 2002; Purwanti, 2021; Yanuarsari et al., 2021). MBKM lahir dari anggapan bahwa belum semua Pendidikan Tinggi di Indonesia mampu menghasilkan lulusan dengan keterampilan dan kemampuan sesuai dunia kerja. Dengan demikian MBKM dikembangkan menjadi program yang berorientasi pada perwujudan pembelajaran yang fleksibel dan otonom di perguruan tinggi guna menciptakan iklim belajar inovatif serta sesuai kebutuhan mahasiswa (Permono et al., 2021; Zuhrohtun et al., 2021) dan juga dapat memenuhi tantangan dunia kerja (Puspitasari \& Nugroho, 2021). Menurut Fuadi \& Aswita (2021), kampus merdeka memiliki arti: (1) adanya otonomi Perguruan Tinggi baik PTN maupun PTS; (2) Program reakreditasi otomatis; (3) Kebebasan bagi PTN Badan Layanan Umum (BLU) dan PTN Satuan Kerja (Satker) untuk menjadi PTN Badan Hukum; (4) Hak belajar selama tiga semester di luar program studi.

Kebijakan MBKM ini relatif baru diterapkan di Indonesia dan nyaris bersamaan dengan pandemi Covid-19. Layaknya kebijakan baru, kebijakan MBKM ini tidak lepas dari pro kontra. Banyak yang memperdebatkan dan mengkritik kebijakan ini, sementara beberapa pihak menyambut dan memberikan dukungan akan pelaksanaan kebijakan ini (Purwanti, 2021). MBKM yang memberikan warna baru bagi ranah kuliah diluar kampus dengan kondisi covid 19 yang melanda di Indonesia, tentu menjadi suatu tantangan baru bagi kebijakan ini. Namun, dalam prokontra tersebut, MBKM tetap mampu disambut secara baik didunia perguruan tinggi. Universitas Flores sebagai salah satu perguruan tinggi swasta di Nusa Tenggara Timur, mampu tetap mengimplementasikan kebijakan tersebut. Dalam kebijakannya, Universitas Flores terus melaksanakan dan mengimplementasikan hasil kebijakan tersebut disetiap program studi yang ada di Universitas Flores. Program Studi Ilmu Hukum, Fakultas Hukum, Universitas Flores turut mengindahkan kebijakan implementasi MBKM tersebut.

Dalam implementasinya, tentu dirasa penting untuk melihat sejauh mana kegiatan implementasi tersebut berjalan. Dengan kata lain, perlu dilakukan survei untuk melihat sejauh mana Implementasi MBKM dapat berjalan terlebih dimasa pandemic covid 19 (Meke, Astro \& Daud, 2021; Laga, dkk., 2021). Hail ini tentu membantu baik pihak perguruan tinggi maupun program studi untuk bisa mengetahui minat, kendala dan juga rencana tindak lanjut yang dapat dijadikan bahan evaluasi dan juga konsep dalam penentuan strategi berikutnya (Nona, dkk., 2021). Berdasarkan latar belakang tersebut dan merespon akan diterapkannya konsep kampus merdeka dan menyiapkan mahasiswa, tim survei MBKM Universitas Flores bekerjasama dengan Kementerian Pendidikan, Kebudayaan, Riset dan Teknologi, melakukan penelitian untuk melihat dampak dan persepsi penerapan MBKM kepada seluruh mahasiswa program studi Ilmu Hukum dengan tujuan untuk melihat sejauh mana pemahaman dan persepsi mahasiswa program studi Ilmu Hukum dan dampak dari penerapan program MBKM yang ada di Universitas Flores.

\section{METODE PENELITIAN}

Penelitian ini merupakan penelitian deskriptif kuantitatif (Arikunto, 2010), menggunakan metode survei. Data diperoleh dari populasi sejumlah 380 responden yang merupakan mahasiswa Program Studi Ilmu Hukum Universitas Flores. Instrumen pengumpulan data menggunakan kuesioner yang telah dibuat oleh Kementerian Pendidikan, Kebudayaan, Riset dan Teknologi (Kemendikbudristek) melalui aplikasi SPADA Dikti. Kuesioner daring yang disediakan menggunakan format kuesioner campuran, gabungan antara pertanyaan tertutup dan terbuka. Pengumpulan data berlangsung pada Desember 2021 untuk selanjutnya dianalisis menggunakan analisis deskriptif. Analisis menggunakan standar baku yaitu diagram hasil jawaban 
936 Persepsi Mahasiswa Terhadap Desain Implementasi Merdeka Belajar Kampus Merdeka: Survei pada Program Studi Ilmu Hukum Universitas Flores - Konstantinus Denny Pareira Meke, Richardo Barry Astro, Christina Bagenda, Sumirahayu Sulaiman, Paulinus Seda, Ana Maria Gadi Djou

DOI: https://doi.org/10.31004/edukatif.v4i1.2060

dari mahasiswa yang disajikan menggunakan informasi data statistik (Bethlehem, 2009). Penelitian ini menggunakan data primer yang dianalisis melalui pemetaan hasil tiap butir pertanyaan yang digunakan dalam kuesioner. Setiap butir pertanyaan yang terdapat dalam kuesioner akan disimpulkan secara prosedural. Hasil grafik tiap pertanyaan yang telah diperoleh kemudian digunakan sebagai evaluasi, dan digunakan sebagai strategi dalam menentukan kebijakan lanjutan di tingkat program studi. Selain itu, hasil penelitian ini akan digunakan sebagai adaptasi atas kajian kegiatan merdeka belajar kampus merdeka tentang perencanaan, proses pembelajaran, penilaian dan evaluasi pembelajaran (Baharuddin, 2021).

\section{HASIL DAN PEMBAHASAN PENELITIAN}

Penelitian ini dilakukan untuk mengukur persepsi dan dampak dari penerapan MBKM Program Studi Ilmu Hukum, Universitas Flores. Responden yang berhasil dihimpun mencapai 379 orang (99,74\%) dari total mahasiswa aktif Program Studi Ilmu Hukum, Fakultas Hukum, Universitas Flores. Mayoritas responden berasal dari angkatan 2021 sejumlah 130 orang $(31,7 \%)$.

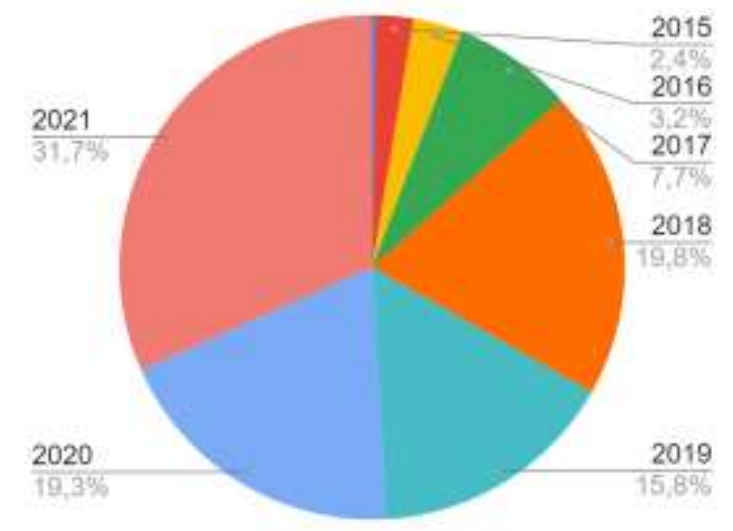

\section{Gambar 1. Sebaran Responden Mahasiswa Program Studi Ilmu Hukum}

Survei terhadap desain implementasi MBKM ini terdiri dari 22 butir pertanyaan dengan pilihan jawaban yang disesuaikan dengan kebutuhan survei oleh tim SPADA Dikti. Pada pertanyaan pertama, jika responden menjawab mengetahui kebijakan MBKM maka akan berlanjut ke pertanyaan berikutnya secara berurutan hingga akhir pertanyaan survei. Sebaliknya jika responden memilih jawaban belum mengetahui sama sekali kebijakan MBKM maka pertanyaan 2-21 akan dilewatkan dan otomatis dialihkan langsung ke pertanyaan akhir (22). Bagan alir pertanyaan survei ditampilkan pada Gambar 2.

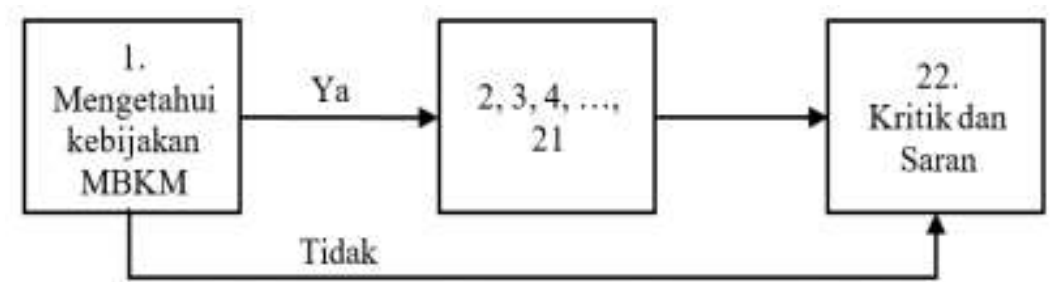

\section{Gambar 2. Bagan alir pertanyaan survei MBKM}

Pada pertanyaan pertama disediakan empat pilihan jawaban yakni: (a) mengetahui kebijakan secara keseluruhan, (b) mengetahui sebagian besar isi kebijakan, (c) mengetahui sedikit, dan (d) tidak mengetahui sama sekali. Dari hasil analisis survei diketahui sebanyak 326 responden mengetahui kebijakan MBKM dengan rincian 48 (12,7\%) mengetahui secara keseluruhan, 79 (20,8\%) mengetahui sebagian besar, dan 199 $(52,5 \%)$ menjawab mengetahui sedikit kebijakan MBKM. Sedangkan 53 responden lainnya $(14,0 \%)$ memilih jawaban tidak mengetahui sama sekali. Berdasarkan jawaban tersebut maka 53 responden tersebut langsung berpindah ke soal nomor 22. Proporsi jawaban untuk pertanyaan satu disajikan pada Gambar 3. 
937 Persepsi Mahasiswa Terhadap Desain Implementasi Merdeka Belajar Kampus Merdeka: Survei pada Program Studi Ilmu Hukum Universitas Flores - Konstantinus Denny Pareira Meke, Richardo Barry Astro, Christina Bagenda, Sumirahayu Sulaiman, Paulinus Seda, Ana Maria Gadi Djou

DOI: https://doi.org/10.31004/edukatif.v4i1.2060

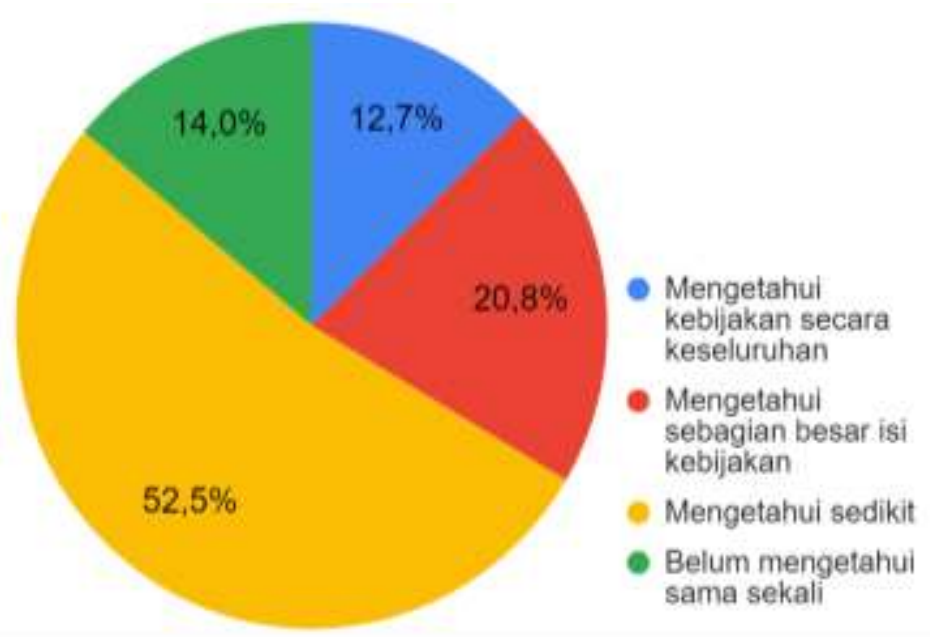

\section{Gambar 3. Hasil Survei untuk Pengetahuan Mahasiswa Mengenai Kebijakan MBKM}

Pada pertanyaan 2 dan 3 responden diuji lebih jauh terkait pemahaman akan kebijakan MBKM, khususnya jumlah semester dan sks yang dapat diambil di luar Perguruan Tinggi asal. Berdasarkan Peraturan Menteri Pendidikan dan Kebudayaan tentang Standar Nasional Pendidikan Tinggi No. 3 Tahun 2020, kegiatan MBKM di luar Perguruan Tinggi asal dapat berlangsung hingga 2 semester atau setara 40 sks. Pada pertanyaan 2 dengan format pertanyaan tertutup, terdapat 89 responden $(27,3 \%)$ yang menjawab secara tepat 2 semester. Sedangkan untuk pertanyaan 3 dengan format pertanyaan terbuka (numerik), hanya 12 responden $(3,7 \%)$ yang menjawab secara tepat 40 sks penyetaraan kegiatan MBKM di luar PT asal. Secara umum pada kedua soal ini terlihat mayoritas responden belum memahami dengan baik kebijakan MBKM terkait pemenuhan masa dan beban belajar khususnya di luar Perguruan Tinggi asal. Hal ini menunjukan minimnya sosialisasi yang menjangkau responden dan/atau rendahnya minat responden untuk mencari informasi terkait kebijakan MBKM. Di samping itu Program Studi Ilmu Hukum sendiri juga belum memberlakukan kurikulum MBKM untuk tahun akademik 2021/2022 yang diduga menyebabkan mahasiswa belum menaruh atensi khusus pada kebijakan ini. Namun khusus untuk nomor 3, rendahnya persentase jawaban benar patut diduga akibat ketidaktelitian responden mencerna soal yang serupa dengan nomor 2. Hal ini terlihat dari mayoitas responden menjawab kurang dari 40 sks, 203 (53,6\%) diantaranya menjawab antara 1-5 sks dan secara spesifik terdapat 56 responden yang menuliskan jawaban " 2 ".

\section{Sumber informasi kebijakan MBKM}

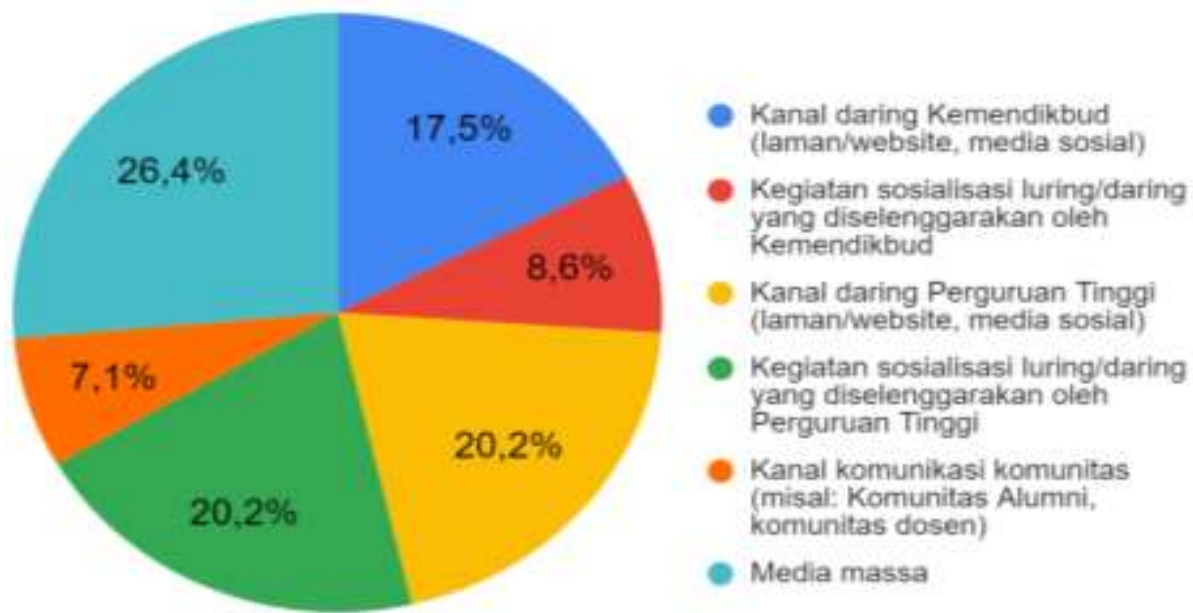

Gambar 4. Hasil Survei untuk sumber informasi kebijakan MKM 
938 Persepsi Mahasiswa Terhadap Desain Implementasi Merdeka Belajar Kampus Merdeka: Survei pada Program Studi Ilmu Hukum Universitas Flores - Konstantinus Denny Pareira Meke, Richardo Barry Astro, Christina Bagenda, Sumirahayu Sulaiman, Paulinus Seda, Ana Maria Gadi Djou

DOI: https://doi.org/10.31004/edukatif.v4i1.2060

Media informasi untuk meningkatkan pemahaman kebijakan MBKM

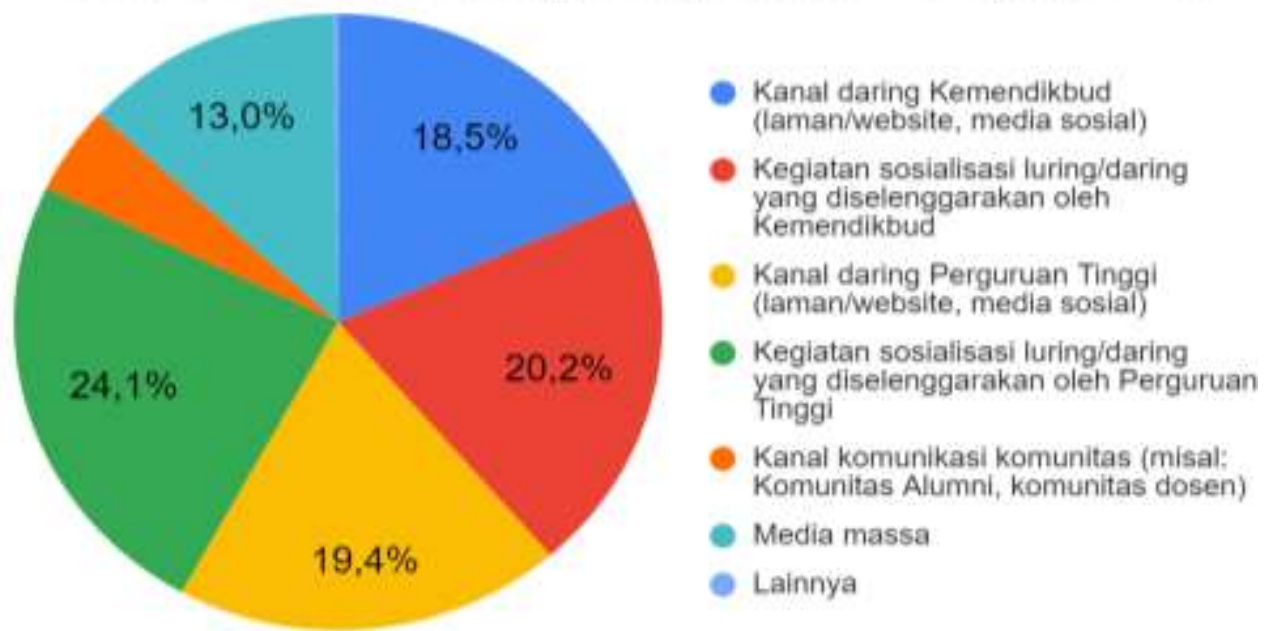

\section{Gambar 5. Hasil Survei untuk Media informasi efektif untuk meningkatkan pemahaman akan kebijakan MBKM}

Lebih lanjut responden diminta untuk memilih media/platform yang selama ini menjadi sumber informasi MBKM (nomor 4), dan juga diminta merekomendasikan 3 media yang paling efektif digunakan untuk penyebarluasan informasi kebijakan MBKM (nomor 5). Berdasarkan Gambar 4, media massa menjadi sumber informasi yang paling banyak memberi informasi terkait kebijakan MBKM dengan 26,4\% (86 responden). Meski demikian, terlihat distribusi yang cukup merata dari berbagai platform yang turut berkontribusi memberi informasi kebijakan MBKM. Pada Gambar 5, media yang paling efektif untuk meningkatkan pemahaman akan kebijakan MBKM yang dipilih responden adalah kegiatan sosialisasi daring/luring baik yang diselenggarakan oleh PT $(24,1 \%)$ maupun oleh Kemendikbud (20,2\%). Hal ini sejalan dengan pendapat dari (Baharuddin, 2021) dan (Fuadi \& Aswita, 2021) yang menekankan pentingnya sosialisasi kebijakan MBKM yang dilakukan Perguruan Tinggi sebagai tempat mahasiswa belajar.

Pada 3 pertanyaan selanjutnya, responden akan diuji terkait pemahamannya akan program-program, MBKM terutama kegiatan belajar di luar Program Studi. Pada pertanyaan ke-6, responden diminta mengkonfirmasi terkait ada atau tidaknya program terdahulu yang serupa dengan bentuk kegiatan MBKM. Sebanyak 200 responden $(61,3 \%)$ yang menjawab "ada" akan berlanjut pada pertanyaan nomor 7 yakni mengidentifikasi bentuk kegiatan tersebut dalam format pertanyaan tertutup dan boleh memilih lebih dari satu pilihan jawaban. Sedangkan $38,7 \%$ responden lainnya yang menyatakan "tidak ada" akan melewati pertanyaan ke-7 dan langsung diarahkan menjawab pertanyaan ke-8. Adapun perbedaan jawaban yang kontras pada pertanyaan ke-6 patut diduga berkaitan dengan minimnya pemahaman mahasiswa akan kebijakan dan program MBKM. Pada kenyataannya, program-program seperti Kuliah Kerja Nyata Tematik (KKNT) dan praktek kerja merupakan program reguler dan termuat dalam dokumen kurikulum Program Studi Ilmu Hukum. Hal ini sejalan dengan hasil analisis untuk pertanyaan ke-7 yang menunjukkan kedua program tersebut mayoritas dipilih oleh responden $(55,1 \%)$. Sedangkan program lain seperti proyek kemanusiaan, proyek independen, dan penelitian masih bersifat insidental. 
939 Persepsi Mahasiswa Terhadap Desain Implementasi Merdeka Belajar Kampus Merdeka: Survei pada Program Studi Ilmu Hukum Universitas Flores - Konstantinus Denny Pareira Meke, Richardo Barry Astro, Christina Bagenda, Sumirahayu Sulaiman, Paulinus Seda, Ana Maria Gadi Djou

DOI: https://doi.org/10.31004/edukatif.v4i1.2060

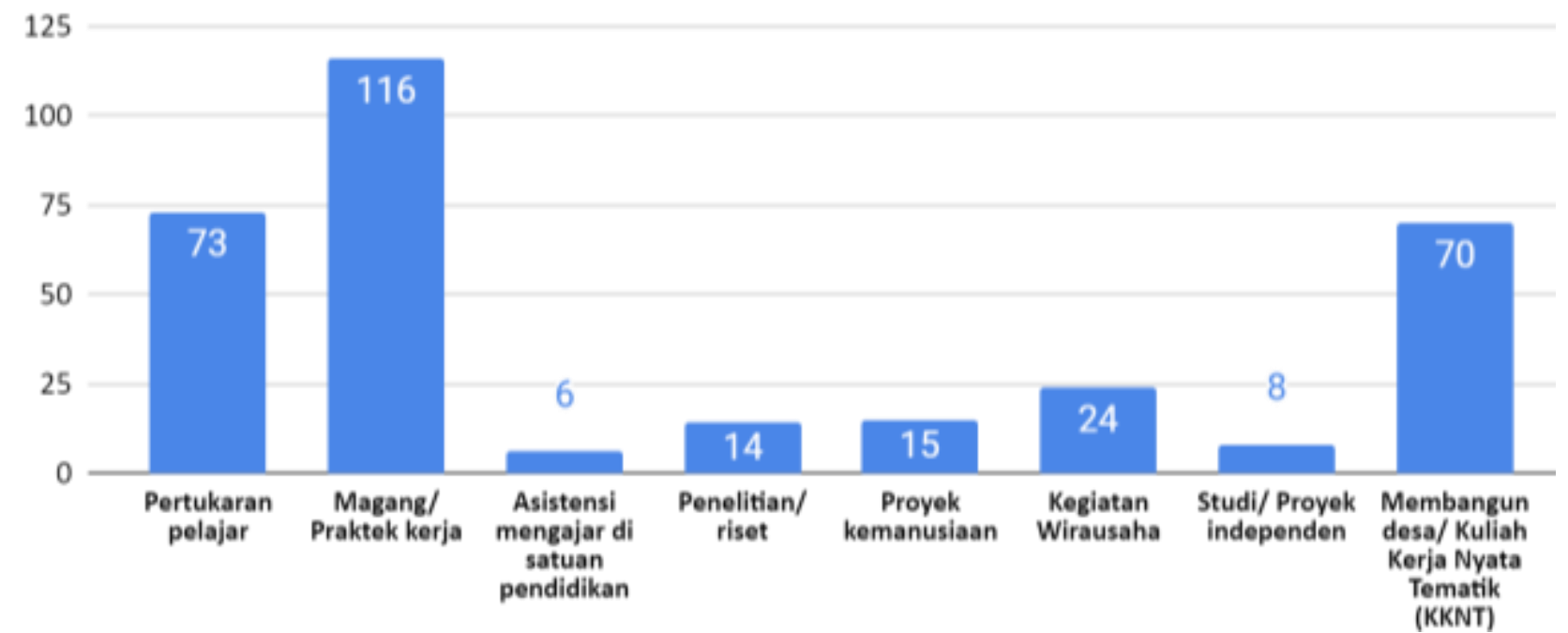

Gambar 6. Pilihan kegiatan belajar di luar Program Studi yang paling diminati mahasiswa Ilmu Hukum

Lebih lanjut pada pertanyaan ke-8 responden diminta untuk memilih bentuk kegiatan pembelajaran di luar Program Studi yang paling diinginkan. Pertanyaan ini menggunakan format pertanyaan tertutup dan responden hanya boleh memilih satu pilihan jawaban. Hasil analisis menunjukkan pilihan responden cukup beragam sebagaimana yang ditampilkan pada Gambar 6. Magang/praktek kerja, dan program membangun desa/KKNT yang telah dikenal sebelumnya masih menjadi pilihan mayoritas responden. Sejalan dengan pendapat Aswita (2021), kegiatan magang/praktek kerja merupakan kegiatan yang penting dan cukup berkontribusi meningkatkan keterampilan dan memberi pengalaman nyata sehingga lulusan lebih siap terjun ke dunia kerja. Selain itu kegiatan pertukaran pelajar yang juga cukup banyak dipilih oleh responden mengindikasikan ketertarikan mahasiswa Ilmu Hukum Universitas Flores untuk merasakan atmosfir pembelajaran baik di Program Studi lain pada PT yang sama maupun program studi sejenis pada PT lain.

Pada pertanyaan ke-9 responden akan digali pengetahuannya akan keberadaan dokumen kurikulum, serta panduan dan prosedur operasional MBKM di Program Studi Ilmu Hukum Universitas Flores. Hasil analisis menunjukkan bahwa 38,7\% responden menjawab belum tersedia, 25,8\% responden menyatakan tidak tahu, sedangkan sisanya 35,6\% responden menjawab sudah tersedia. Kenyataannya Program Studi Ilmu Hukum Universitas Flores belum menyelenggarakan kurikulum MBKM. Munculnya jawaban sudah tersedianya dokumen MBKM pada program studi responden disinyalir berangkat dari argumen bahwa program-program seperti KKN/KKNT yang sesuai dengan bentuk kegiatan MBKM telah diterapkan secara reguler di Universitas Flores. Sehingga responden berasumsi bahwa kurikulum yang dijalankan pada Program Studi Ilmu Hukum dapat dikatakan sebagai kurikulum MBKM dan dengan demikian dokumen yang dimaksud telah tersedia. Demikian pula dengan jawaban "tidak tahu" yang muncul mengindikasikan bahwa kurang ada komunikasi/sosialisasi di tingkat Program Studi terkait kurikulum. Oleh karena itu sejalan dengan pendapat Baharuddin (2021) dan Fuadi (2021), sangat penting untuk segera menggiatkan sosialisasi, terutama kebijakan MBKM ini kepada mahasiswa.

Pertanyaan yang tersisa pada kuesioner selanjutnya berfokus pada persepsi mahasiswa akan dampak implementasi MBKM. Secara umum mahasiswa Program Studi Ilmu Hukum Universitas Flores memiliki persepsi yang positif akan desain dan program MBKM meski dengan tingkat pemahaman akan kebijakan MBKM yang masih tergolong rendah. Pada indikator kesiapan responden menjalani program-program MBKM (pertanyaan ke-10), diperoleh bahwa 74,5\% responden menyatakan siap, sedangkan 24,8\% lainnya menyatakan belum siap dan $0,6 \%$ responden menjawab tidak berminat. Pada indikator impikasi kegiatan MBKM terhadap masa studi (pertanyaan ke-11), responden mayoritas $(69,0 \%)$ berpendapat bahwa lamanya 
940 Persepsi Mahasiswa Terhadap Desain Implementasi Merdeka Belajar Kampus Merdeka: Survei pada Program Studi Ilmu Hukum Universitas Flores - Konstantinus Denny Pareira Meke, Richardo Barry Astro, Christina Bagenda, Sumirahayu Sulaiman, Paulinus Seda, Ana Maria Gadi Djou

DOI: https://doi.org/10.31004/edukatif.v4i1.2060

masa studi tidak akan terganggu (tetap tepat waktu). Disisi lain, 12,3\% responden mengkhawatirkan kegiatan MBKM khususnya belajar di luar program studi akan berimbas pada lamanya masa studi, dan 18,7\% lainnya menjawab tidak tahu.

Terkait dampak kegiatan MBKM terhadap penguasaan kompetensi tambahan, respon positif kembali diperoleh dari mahasiswa Ilmu Hukum Universitas Flores. Untuk pertanyaan ke-12, sebanyak 275 responden $(84,4 \%)$ meyakini bahwa pembelajaran di luar kampus akan memberikan kompetensi tambahan terutama keterampilan menganalisis, dan etika profesi. Mayoritas responden juga percaya bahwa program yang ditawarkan dalam MBKM akan memberi kompetensi tambahan sesuai kebutuhan disamping kompetensi utama yang diperoleh dari Program Studi, serta memperluas perspektif mahasiswa (pertanyaan ke-13).

Pada indikator kebermanfaatan program dalam upaya pengembangan keterampilan/kompetensi (pertanyaan ke-15), sebanyak 208 responden $(63,8 \%)$ juga menyatakan bahwa MBKM sangat bermanfaat dan $116(35,6 \%)$ lainnya menyatakan cukup bermanfaat. Responden juga meyakini kegiatan MBKM akan berdampak pada peningkatan soft skill minimal cukup baik sebagai bekal kerja pasca lulus (pertanyaan ke-16). Mayoritas responden (99,7\%) juga meyakini program MBKM ini relevan dengan kebutuhan lulusan di masa mendatang (pertanyaan ke-19) sebagaimana yang ditampilkan pada Gambar 6. Dengan demikian, mayoritas responden beranggapan bahwa kegiatan MBKM penting untuk mempersiapkan mahasiswa menghadapi masa setelah kuliah (pertanyaan ke-17), hanya menyisakan 1 responden yang beranggapan sebaliknya. Optimisme mahasiswa akan kebermanfaatan program MBKM ini sejalan dengan pendapat (Latifah et al., 2021) yang berpendapat bahwa program MBKM mampu menyiapkan lulusan dan relevan dengan dunia kerja.

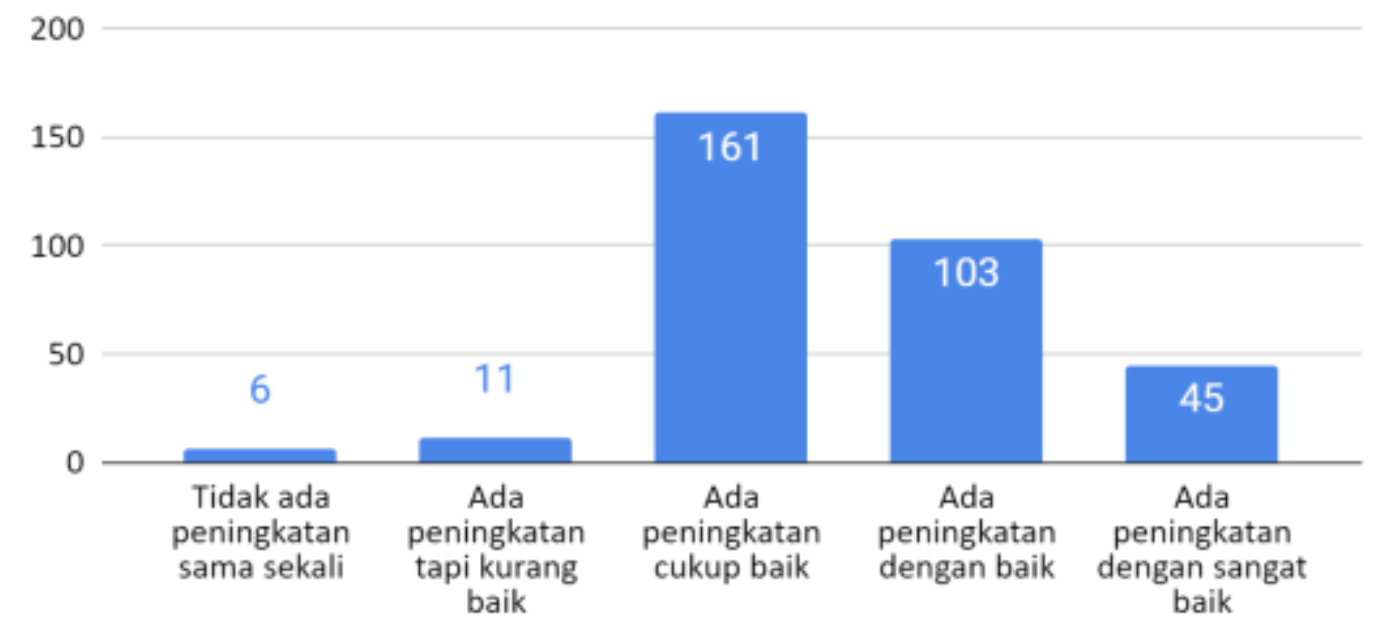

\section{Gambar 7. Hasil survei dampak peningkatan soft skill setelah mengikuti kegiatan MBKM}

Lebih lanjut, meskipun terdapat $78,5 \%$ responden yang menyatakan ketertarikannya akan program MBKM (pertanyaan ke-20), terdapat pula kekhawatiran mahasiswa untuk menjalankan kegiatan tersebut. Hasil survei pada pertanyaan butir 18 menunjukkan kekhawatiran mahasiswa untuk menjalani MBKM, diantaranya: 58,8\% mengkhawatirkan pengeluaran biaya yang lebih besar, 25,7\% mencemaskan kurangnya informasi akan kebijakan MBKM, serta masing-masing 8,0\% dan 7,5\% responden mengkhawatirkan kurangnya dukungan orang tua dan Perguruan Tinggi. Aspek biaya dan minimnya informasi sebagai alasan utama kekhawatiran menjalankan kegiatan MBKM sangat bisa dimaklumi mengingat mayoritas mahasiswa Universitas Flores berasal dari kalangan kurang mampu serta minimnya sosialisasi dari para pihak yang berkepentingan.

Terlepas dari kekhawatiran yang ada, mayoritas responden $(78,5 \%)$ tetap memilih sangat tertarik dengan program MBKM (pertanyaan ke-20). Hal ini dapat dipahami mengingat MBKM menjadi salah satu kebijakan yang dipandang mampu beradaptasi dengan perkembangan jaman dan tantangan dalam menghadapi 
941 Persepsi Mahasiswa Terhadap Desain Implementasi Merdeka Belajar Kampus Merdeka: Survei pada Program Studi Ilmu Hukum Universitas Flores - Konstantinus Denny Pareira Meke, Richardo Barry Astro, Christina Bagenda, Sumirahayu Sulaiman, Paulinus Seda, Ana Maria Gadi Djou

DOI: https://doi.org/10.31004/edukatif.v4i1.2060

persaingan global (Krisnanik et al., 2021). Adapun persiapan yang diperlukan oleh mahasiswa guna mengatasi kekhawatiran akan minimnya informasi untuk implementasi MBKM yang lebih optimal, berdasarkan butir pertanyaan 14 diketahui sebanyak 57,5\% responden memilih perlu mempelajari panduan dan kurikulum MBKM, 22,6\% memilih mengikuti seleksi kegiatan MBKM, serta 19,9\% responden memilih untuk proaktif mempersiapkan pembelajaran yang sesuai dengan desain kurikulum MBKM.

Pada pertanyaan akhir, keseluruhan 379 responden memberikan kritik dan saran terkait kebijakan dan desain implementasi MBKM. Mayoritas responden mengkritik minimnya sosialisasi yang menjangkau mahasiswa oleh para pihak yang berkepentingan dan menyarankan untuk segera dilaksanakan sosialisasi di tingkat universitas baik secara daring maupun luring. Selain itu responden juga menekankan agar para pihak memfasilitasi kegiatan-kegiatan, termasuk pendanaan pembelajaran di luar PT agar implementasi MBKM berjalan optimal.

Dari Penelitian tentang Dampak Pelaksanaan MBKM ini tergambar bahwa mahasiswa yakin akan bahwa ada peningkatan terhadap soft skills dan hard skills serta tercapainya kompetensi yang ada dalam diri mereka saat lulus (Rahmawati \& Nurzaelani, 2021). Mahasiswa dituntut mampu menyesuaikan kegiatan pembelajaran tidak hanya didalam perguruan tinggi asal, namun juga di luar program studinya dan diluar perguruan tingginya (Khotimah, Riswanto, Udayati, 2021). MBKM dalam penerapannya dipercaya dan dirancang agar mahasiswa dekat dengan dunia kerja untuk mendorong hasil Pendidikan bisa mengatasi pengangguran (Hairunisya, 2021).

\section{KESIMPULAN}

Hasil penelitian ini menunjukkan secara umum tingkat pemahaman mahasiswa Program Studi Ilmu Hukum Universitas Flores akan kebijakan MBKM masih tergolong rendah. Mayoritas mahasiswa hanya mengetahui sebagian kecil kebijakan MBKM dan kurang memahami hak belajar (jumlah semester dan sks maksimal) di luar Perguruan Tinggi. Mahasiswa Ilmu Hukum juga berpendapat bahwa media informasi yang efektif untuk meningkatkan pemahaman kebijakan MBKM adalah sosialisasi luring/daring baik yang diselenggarakan oleh Perguruan Tinggi maupun oleh Kemendikbud. Bentuk kegiatan pembelajaran di luar program studi yang dipilih mahasiswa relatif beragam, dengan mayoritas kegiatan yang dipilih adalah Kuliah Kerja Nyata Tematik (KKNT) dan magang/praktek kerja. Mahasiswa Ilmu Hukum Universitas Flores juga memiliki persepsi yang baik terhadap desain implementasi MKBK. Mayoritas mahasiswa juga menyatakan bersedia menjalani kegiatan MBKM, dan berkeyakinan kegiatan tersebut tidak berpengaruh terhadap lamanya masa studi. Selain itu, program-program MBKM diyakini bermanfaat untuk meningkatkan kompetensi tambahan dan relevan dengan kebutuhan lulusan di masa mendatang.

\section{UCAPAN TERIMA KASIH}

Ucapan terima kasih disampaikan kepada Direktoral Jendral Pendidikan Tinggi, Riset dan Teknologi, Kementrian Pendidikan, Kebudayaan, Riset dan Teknologi yang telah mendanai penelitian dampak MBKM ini melalui program penelitian MBKM dan pengabdian berbasis riset menggunakan bantuan pendanaan program penelitian kebijakan Merdeka Belajar Kampus Merdeka dan pengabdian kepada masyarakat berbasis hasil penelitian perguruan tinggi swasta tahun 2021. Ucapan terima kasih juga disampaikan kepada Universitas Flores dan Lembaga Penelitian dan Pengabdian Kepada Masyarakat (LP2M) Universitas Flores yang memberikan kesempatan kepada tim peneliti untuk melakukan penelitian ini.

\section{DAFTAR PUSTAKA}

Arikunto, S. (2010). Prosedur Penelitian: Suatu Pendekatan Praktik (Edisi Revisi). Rineka Cipta.

Aswita, D. (2021). Merdeka Belajar Kampus Merdeka (MBKM): Inventarisasi Mitra dalam Pelaksanaan 
942 Persepsi Mahasiswa Terhadap Desain Implementasi Merdeka Belajar Kampus Merdeka: Survei pada Program Studi Ilmu Hukum Universitas Flores - Konstantinus Denny Pareira Meke, Richardo Barry Astro, Christina Bagenda, Sumirahayu Sulaiman, Paulinus Seda, Ana Maria Gadi Djou DOI: https://doi.org/10.31004/edukatif.v4i1.2060

Magang Mahasiswa Fakultas Keguruan dan Ilmu Pendidika. Prosiding Seminar Nasional Biotik, 201206.

Baharuddin, M. R. (2021). Adaptasi Kurikulum Merdeka Belajar Kampus Merdeka (Fokus: Model MBKM Program Studi). Jurnal Studi Guru dan Pembelajaran, 4(1), 195-205.

https://www.e-journal.my.id/jsgp/article/view/591

Bethlehem, J. (2009). Applied Survey Methods: A Statistical Perspective. John Wiley \& Sons, Inc. https://doi.org/https://doi.org/10.1002/9780470494998

Fuadi, T. M. (2021). Konsep Merdeka Belajar-Kampus Merdeka (MBKM): Aplikasinya dalam Pendidikan Biologi. Prosiding Seminar Nasional Biotik, 183-200.

Fuadi, T. M., \& Aswita, D. (2021). Merdeka Belajar Kampus Merdeka (MBKM): Bagaimana Penerapan dan Kedala Yang Dihadapi oleh Perguruan Tinggi Swasta di Aceh. Jurnal Dedikasi Pendidikan, 5(2), 603 614. http://jurnal.abulyatama.ac.id/index.php/dedikasi

Hairunisya, N. . (2021). Analysis Of Teaching Material Development Problems (Implementation Of Independent Learning And Merdeka Campus). Jurnal Pendidikan Tambusai, 5(3), 6984-6994. Retrieved from https://www.jptam.org/index.php/jptam/article/view/2077

Khotimah, N. R., Riswanto, R. \& Udayati. (2021). Pelaksanaan Program Kampus Mengajar di SD Negeri 014 Palembang Sumatera Selatan. Sinar Sang Surya: Jurnal Pusat Pengabdian Kepada Masyarakat, 5(2), 194-204. http://dx.doi.org/10.24127/sss.v5i2.1700

Krisnanik, E., Saphira, Q., \& Indriana, I. H. (2021). Desain Model MBKM dan Kolaborasi Kerja Sama Model Pentahelix Guna Meningkatkan Daya Saing Lulusan. Proceeding KONIK (Konferensi Nasional Ilmu Komputer), 5, 138-142.

Laga, Y. dkk. (2021). Persepsi Mahasiswa Terhadap Kebijakan Merdeka Belajar Kampus Merdeka (MBKM). Edukatif: Jurnal Ilmu Pendidikan. 4(1). 701-710. https://doi.org/10.31004/edukatif.v4i1.1951

Latifah, S., Gibran, Z., Saadiah, H., Prasetyawijaya, G., N.C, A., Imam, A., Mustika, B., Lasmini, N., \& Ahmad, Z. (2021). Pertukaran Pelajar Unram-UPM: Inovasi Pembelajaran Mbkm Dalam Menumbuhkan Ketangguhan Lulusan Sarjana Kehutanan. Jurnal PEPADU, 2, 46-51. https://doi.org/10.29303/jurnalpepadu.v2i1.290

Margiato, H. (2002, September 15). Merdeka Belajar-Kampus Merdeka: Antara Peluang dan Tantangan. Kompas.Com. https://www.kompas.com/edu/read/2020/09/15/094940671/merdeka-belajarkampusmerdeka-antara-peluang-dan-tantangan?page=all

Meke, K. D. P., Astro, R. B. \& Daud, M. H. (2021). Dampak Kebijakan Merdeka Belajar Kampus Merdeka (MBKM) pada Perguruan Tinggi Swasta di Indonesia. Edukatif: Jurnal Ilmu Pendidikan. 4(1), 681-690. https://doi.org/10.31004/edukatif.v4i1.1940

Nona, R. V., dkk. (2021). Persepsi Dosen Universitas Flores Terhadap Program Merdeka Belajar Kampus Merdeka. Edukatif: Jurnal Ilmu Pendidikan. 4(1). 771-780. https://doi.org/10.31004/edukatif.v4i1.1976

Peraturan Menteri Pendidikan dan Kebudayaan tentang Standar Nasional Pendidikan Tinggi, 47 Menteri Pendidikan dan Kebudayaan Republik Indonesia Peraturan Menteri Kesehatan Republik Indonesia 1 (2020).

Permono, P. S., Putra, R. B. A., Anggita, G. M., \& Nugroho, E. (2021). Persepsi Mahasiswa Fakultas Ilmu Keolahragaan tentang Program Merdeka Belajar-Kampus Merdeka. Journal of Sport Coaching and Physical Education, 6(2), 95-103.

Purwanti, E. (2021). Preparing the Implementation of Merdeka Belajar - Kampus Merdeka Policy in Higher Education Institutions. Proceedings of the 4th International Conference on Sustainable Innovation 2020-Social, Humanity, and Education (ICoSIHESS 2020), 518(ICoSIHESS 2020), 384-391.

https://doi.org/10.2991/assehr.k.210120.149

Edukatif : Jurnal Ilmu Pendidikan Vol 4 No 1 Tahun 2022 p-ISSN 2656-8063 e-ISSN 2656-8071 
943 Persepsi Mahasiswa Terhadap Desain Implementasi Merdeka Belajar Kampus Merdeka: Survei pada Program Studi Ilmu Hukum Universitas Flores - Konstantinus Denny Pareira Meke, Richardo Barry Astro, Christina Bagenda, Sumirahayu Sulaiman, Paulinus Seda, Ana Maria Gadi Djou

DOI: https://doi.org/10.31004/edukatif.v4i1.2060

Puspitasari, R., \& Nugroho, R. (2021). Implementasi Kebijakan Merdeka Belajar, Kampus Merdeka Fisip UPN Veteran Jawa Timur. Dinamika Governance : Jurnal Ilmu Administrasi Negara, 11(2), 276-292.

Rahmawati, M. R. \& Nurzaelani, M. M. (2021). Dampak Program Merdeka Belajar Kampus Merdeka Bagi Peningkatan Soft Skills Dan Hard Skills Mahasiswa Fkip Universitas Ibn Khaldun Bogor. Educate : Jurnal Teknologi Pendidikan, 7(1), 37-47. http://dx.doi.org/10.32832/educate.v7i1.6218

Yanuarsari, R., Asmadi, I., Muchtar, S. H., \& Sulastini, R. (2021). Peran Program Merdeka Belajar Kampus Merdeka dalam Meningkatkan Kemandirian Desa. Jurnal Basicedu, 5(6), 1683-1688.

Zuhrohtun, Heriningsih, S., Sunaryo, K., \& Sriyono. (2021). The Merdeka Belajar Kampus Merdeka (MBKM) Collaboration with BUMDes Sari Dewi, Maguwoharjo, Sleman. RSF Conference Series: Business, Management and Social Sciences, 1(3), 411-418. 